https://helda.helsinki.fi

\title{
Corruption in Post-Soviet Uzbekistan
}

\section{Urinboyev, Rustam}

Springer

2018-10-15

Urinboyev , R 2018 , Corruption in Post-Soviet Uzbekistan . in A Farazmand (ed.) , Global

Encyclopedia of Public Administration, Public Policy, and Governance . Springer . https://doi.org/10.1007/978-3-319

http://hdl.handle.net/10138/298402

https://doi.org/10.1007/978-3-319-31816-5_3666-1

publishedVersion

Downloaded from Helda, University of Helsinki institutional repository.

This is an electronic reprint of the original article.

This reprint may differ from the original in pagination and typographic detail.

Please cite the original version. 


\section{Corruption in Post-Soviet} Uzbekistan

\author{
Rustamjon Urinboyev \\ Aleksanteri Institute, \\ University of Helsinki, \\ Helsinki, Finland \\ Sociology of Law Department, \\ Faculty of Social Sciences, \\ Lund University, Lund, Sweden
}

\section{Synonyms}

Informal governance in Uzbekistan; Corruption in Central Asia

\section{Definition}

The international legal definition of corruption refers here to the one presented by Transparency International: "The abuse of entrusted power for private gain" (TI 2016).

The term "mahalla," derived from the Arabic mahali ("local"), is formally used in Uzbekistan to mean neighborhood, local community, or state administrative unit. Today, there are some 12,000 mahallas in Uzbekistan, each of which consists of anything between 150 and 1,500 households. In Uzbekistan, local people also use the word to describe community-based, informal economic practices. In this sense, mahalla denotes the means whereby people obtain access to public goods, services, and social protection while bypassing the state.

\section{Introduction}

The collapse of the Soviet Union in 1991 led to the emergence of 15 independent states, 5 of which were in Central Asian. The Western world proclaimed the collapse as a victory for freedom and a final triumph of democracy over communism. There was a widespread assumption, both inside and outside the post-Soviet space, that the introduction of Western-style political institutions and legal systems would promote good governance and rule of law in post-Soviet societies. However, an analysis of the academic literature and policy reports on these societies indicates that social inequality has apparently increased in the postSoviet period. This has resulted in a growing concentration of wealth in the hands of kleptocratic state officials and business elites who are well connected to the higher echelons of government. It has also contributed to growing poverty among the population in general (cf., Dillinger 2007; Habibov 2011; Hohmann et al. 2014; Humphrey 2002; Luong 2004).

Corruption is one of the main problems in this respect. There have been extensive discussions in academic and policy circles of why corruption 
remains a persistent and pervasive phenomenon in post-Soviet societies (e.g., Karklins 2002; Knack 2006; Polese 2008; Rivkin-Fish 2005; Urinboyev and Svensson 2013; Wanner 2005; Werner 2000). This chapter presents a further study in this direction and focuses on the case of post-Soviet Uzbekistan, about which, due to the authoritarian nature of the political regime, only a limited amount of information and data are available. Uzbekistan is also an internationally significant (yet under-researched) case given its position as one of the most corrupt countries in the world according to the Transparency International's (TI) Corruption Perceptions Index (TI 2016). The purpose of this chapter is thus to explore and delineate the factors and processes that explain the emergence and ubiquity of corruption in Uzbekistan, to analyze the current anticorruption situation and efforts in the country, and then to suggest areas of governance reform as well as avenues for future research.

\section{Corruption and Informal Governance in Uzbekistan: The Karimov Era}

Uzbekistan, like other newly independent postSoviet states, was faced with the complex task of building a new nation-state. Coming on the heels of the global (Western) good governance discourses, the political leadership of Uzbekistan made all sorts of bold claims about their strong commitment to the ideals of democracy, market economy, human rights and the rule of law, as well as their intention to dismantle the Soviet-style governance (cf., Perlman and Gleason 2007). At the same time, Uzbek authorities made it clear that its governance system, while adhering to global standards, would also deploy Uzbekistan's ancient traditions, rich Islamic heritage and centuries-old administrative traditions in the nation-building project (Karimov 1993). Many international organizations, such as the World Bank, IMF, and UNDP, promptly geared their development programs to the Uzbek authorities' reform agenda, financing and initiating innumerable good governance, market economy, and human rights projects.
However, the complex and multidimensional nature of the political stability challenges that Uzbekistan faced in the 1990s, for different reasons, made the government skeptical towards real democratization and market reforms. The need to prioritize political stability over reforms was justified by the unstable political situation in Central Asia during the 1990s. This included ethnic clashes between the Uzbeks and the Turks in 1989, ethnic conflicts between the Uzbek and Kyrgyz people in southern Kyrgyzstan in 1990, and the civil war in neighboring Tajikistan, 1992-1997 (Fane 1996; Megoran 2017; Warikoo and Norbu 1992). Consequently, the Uzbek authorities made it clear from the beginning that the "big bang" or shock therapy approach to transition would not be suitable for Uzbekistan (Ruziev et al. 2007). Instead, Uzbekistan adopted a gradualist approach, maintaining Soviet-era welfare policies and centralized control over the priority sectors of the economy (Spoor 1995). Thus, preserving the stability of the economy and of the social and political order has since become an overarching rationale for rejecting the economic and political reforms recommended by international institutions and for developing a strict border regime (Fumagalli 2007).

Notably, during the early years of transition, Uzbekistan achieved small but positive and persistent economic growth due to its favorable economic conditions such as the dominance of agricultural production, the low level of initial industrialization, and the rich natural resource base (Zettelmeyer 1998). Uzbekistan suffered less from the transition depression than its neighboring Central Asian states and was among the first to report positive output growth for the first time in 1996 (Spechler 2002). The cumulative decline in GDP between 1989 and 1996 was the lowest in Uzbekistan among all former Soviet republics. Uzbekistan did fairly well in terms of providing a social safety net, alleviating poverty and limiting spending cuts in education and health care, especially in the mid-1990s (Johnson 2007; Pomfret 2000). Soviet-style centralized economic management and strong social protection measures seemed to be successful in the transition period, as they prevented large output decline 
and served to maintain a reasonable standard of living. The agricultural sector prevented the increase of unemployment by providing job opportunities in rural areas. In this respect, during the early years of transition, Uzbekistan maintained Soviet-era welfare policies and centralized control over the priority sectors of the economy since these policies had considerably contributed to political stability and security.

However, the gradual reform strategy appeared to be a short-term remedy. The gradualist approach to transition did indeed contribute to the prevention of a sharp output loss and the consequential rise in unemployment and social unrest during the early years of transition. In spite of this, by 2000, it became evident that the economy was simply stagnating (Kandiyoti 2007). This was largely due to the government's heavy involvement in maintaining the practice of centralized management over the key sectors of the economy, which created significant administrative barriers and a high tax burden, thereby causing high transaction costs for national business and the prevalence of an informal economy (Ergashev et al. 2006). As Kandiyoti (2007) maintains, the partial market reforms that the government of Uzbekistan implemented in pursuit of stability paradoxically resulted in inefficient resource allocation and widespread corruption that led to a significant retrenchment of the welfare state. The centralized management methods negatively affected the agricultural sector in particular, which was evidenced by the government actively intervening in the cotton sector by redistributing income from agriculture. This was done in order to develop industries that produced import substitutes. Since agriculture has traditionally been the main shock-absorbing structure in rural areas, the reallocation of resources from agriculture to industry negatively affected the living standard of the rural population (Ilkhamov 2004; World Bank 1999). At the same time, the government took a series of severe measures to liquidate, or formalize, informal economic activities (bazaars and petty cross-border trade), which provided alternative means of survival for hundreds of thousands of people (Ilkhamov 2013). Although the Uzbek economy is said to have been experiencing above-trend rates of growth (7-8\%) since 2004 (IMF 2012), these indicators hardly reflect the everyday realities in Uzbekistan in which many people, especially in rural areas, are compelled to secure their livelihood needs through alternative sources of income and a social safety net (Rasanayagam 2011; Urinboyev 2013).

These developments led to the emergence of informal governance structures in Uzbekistan (Urinboyev et al. 2018). As the state retreated from its social welfare obligations and failed to provide formal income-earning opportunities, citizens reacted to these changes by devising informal coping strategies (Urinboyev and Svensson 2017). Many commentators now argue that Uzbekistan has made little progress in promoting the rule of law and good governance, and that corruption has become a part and parcel of everyday life (Ilkhamov 2017; Kandiyoti 2007; Lewis 2016; Markowitz 2008; Rasanayagam 2011; Trevisani 2007; Urinboyev and Svensson 2013). According to the Corruption Perceptions Index, released annually by Transparency International, Uzbekistan has regularly been ranked among the most corrupt countries in the world (TI 2016). The "control of corruption" indicator of the World Bank Governance Studies also shows an extremely high level of corruption in Uzbekistan (World Bank 2014). Although Uzbekistan acceded to the UN Convention against Corruption in 2008 and recently adopted an Anti-Corruption Law on January 4, 2017, no significant success in reducing corruption has been apparent. The latest policy report, Tackling Corruption in Uzbekistan, commissioned by the Open Society Foundations Eurasia Program shows that the Uzbek authorities' recent anticorruption drives largely reflect political maneuverings in the elite, rather than a genuine attempt to combat corruption (Lewis 2016).

Academically, there is a growing body of literature on Uzbekistan's governance trajectories. Much of the scholarly literature, especially anthropological accounts, demonstrates that corruption permeates all levels of the state and society, from daily interactions between ordinary citizens and low-level state officials to kleptocratic practices involving high-level state officials 
(e.g., Abramson 2000; Ilkhamov 2017; Kandiyoti 2007; Markowitz 2008; Perlman and Gleason 2007; Rasanayagam 2011; Taksanov 2000; Wegerich 2006). Much of this research concentrates on macrolevel topics and state-centered approaches that focus on: authoritarianism and the persistence of a Soviet-style administrative culture, predatory elites, a dysfunctional public administration system, illiberal economic policies, clan politics, post-Soviet agricultural reforms, corrupt law-enforcement structures, and inadequate ways of dealing with corruption on the part of state authorities. These authors argue that the struggles among various state actors to gain control over scarce resources have resulted in an inefficient resource allocation and contradictory state policies, thereby making corruption and bribery part of the governance mode in Uzbekistan. At the same time, these studies also claim that there is a need to distinguish between the informal practices of kleptocratic elites, which have nothing to do with "survival," and the informal coping strategies of ordinary citizens and low-level officials. Another body of scholarly works suggests that it is the penetration of clans and regional patronage networks into official structures that depletes the state's organizational powers and causes corruption in state institutions (Collins 2003; Ilkhamov 2007; Kubicek 1998; Luong 2004; Pashkun 2003). Others have explained the ubiquity of corruption in Uzbekistan as an outcome of its communist past (Ergashev et al. 2006; Gleason 1995; Staples 1993).

The above studies share two common features in terms of analyzing corruption in Uzbekistan. First, they explain the ubiquity of corruption with reference to the authoritarian nature of the political regime. This idea is consistent with the mainstream corruption literature in which a strong state is seen as the key driver of widespread corruption, especially when it tends to function as a totalitarian and monopolizing agent (e.g., Heidenheimer et al. 1989; Sun 2004; Varese 2001). Second, they reflect the "corruption of the weak" approach, in which informal or illegal practices are seen as a survival strategy that provides alternative means for ordinary residents and low-level state officials to secure their basic needs (De Sardan 1999;
Ledeneva 2013; Polese 2008; Sneath 2002). While recognizing the importance of "strong state" explanations, it should be noted that they are not sufficient, and run the risk of aggrandizing the role of the state as being the prime mover of widespread corruption, as if it alone shapes the basic patterns of economic life and determines the parameters of daily social relations. Moreover, survival strategy explanations cannot satisfactorily explain the nonmonetary and affective dimensions of informal transactions. These needs to be considered when studying corruption in traditional, collectivist societies like Uzbekistan where society is organized around kinship networks. Of course, economic motivations play a major role in informal transactions, but the fashions and rituals in which they take place show a high degree of embeddedness in social norms, traditions, moral codes, and affective logics. Hence, to gain a more nuanced understanding of the nature, causes and forms of corruption in Uzbekistan, there is also a need to focus on the everyday life and social interactions on a microlevel.

\section{The Basic Social Fabric of Uzbek Society}

Having been under the Soviet planning system for more than 70 years, Uzbekistan embodies a peculiar blend of traditionalism and modernity. As Pashkun (2003) describes, the ruling elite is quite Westernized (Russified), while a large portion of society, especially the rural inhabitants who account for more than $60 \%$ of the population, are still strongly devoted to traditions, collectivism, family, kinship, and religious values (Pashkun 2003; Poliakov 1992). This implies that the behavioral imperatives, expectations, and social sanctions emanating from these traditional structures largely shape the basic parameters of everyday life and social relations in Uzbek society (Urinboyev and Svensson 2017). These processes become particularly evident when observing the social interactions in the realm of the mahalla (neighborhood community), a primary social institution that deserves special attention when examining corruption in Uzbekistan. 
As the state in contemporary Uzbekistan is no longer able to provide jobs and social services, Uzbek people frequently rely on social safety nets and mutual aid practices within their mahalla and kinship networks. These practices serve as a shock-absorbing institution for many people, enabling them to secure their basic needs and gain access to public goods, services and social protection unavailable from the state. Typically, such mahalla-based mutual aid practices include monetary and labor exchanges, rotating savings and credit initiatives, noncompensated labor during life-cycle rituals, housing construction and contributions to charity. Hence, few wedding feasts, funerals, irrigation building, road asphalting, medical operations or house constructions take place in the life of villagers without family, kinship or mahalla support. For example, according to Uzbek social norms, people are expected to give a fixed amount of money to the host when they attend wedding feasts. People actively engage in such mutual aid activities, since these practices enable them to not only meet their livelihood needs but also provide space for participation in everyday life and social interactions.

These mutual aid practices create strong moral and affective bonds within the realm of mahalla life. Uzbek people regularly attend most of the socializing events together and have a relationship of mutual dependence. The fact that people meet one another on a daily basis and regularly interact at social events acts as a guarantee that mahalla pressure and sanctions can be applied to an individual or his family who are not acting fairly, or are not helping a neighbor or mahalla member. Consequently, there is a high probability that people will help their family, kin, or mahalla members when they need assistance. Relying on kinship and mahalla connections is also a way to make up for the "absent state". Hence, the give-and-take rituals constitute an integral part of everyday interactions in Uzbek society.

While the aforementioned mutual aid practices produce social solidarity and reinforce the basic social fabric of Uzbek society, they may also contribute to the emergence of the initial elements of corruption. According to the informal mahalla norms, the individual is expected to share his or her economic resources and political influence with the mahalla (family, kinship group, neighbors). These norms shape the behavior of individuals when they engage in public administration or wield some political or economic resources. In this regard, the state officials have little room for individual choice and often find themselves torn between loyalty to their family, kin, and mahalla and honesty at work. Thus, upholding respect and loyalty for family, kin, and mahalla networks often comes at the expense of using/abusing one's public office, thereby leading to an omnipresence of informal and illegal practices in state institutions (cf. Urinboyev and Svensson 2013, 2017). In this way, mahalla-based social practices undermine the rule of law and good governance initiatives by promoting alternative versions of how people should behave. Perlman and Gleason also share this perspective, noting that the "Asian path is different from other competing approaches in that it is synthetic-binding together the interests of the state, the society, the family, and the individual" (2007, p. 1333). Hence, the behavioral instructions promoted by the mahalla influence social behavior and everyday life more effectively than the laws of the state. Although these social practices can be interpreted as an instance of "corruption" according to the international legal definitions thereof, they are accepted within mahalla norms and traditions as a legitimate practice regardless of whether they are legal or illegal.

\section{Governance and Anticorruption Policies in the Post-Karimov Period}

The account presented in this entry mainly reflects the state of everyday life under President Islam Karimov (1991-2016) whose quarter-century rule in Uzbekistan had left rampant corruption and a stagnant economy that resulted in massive labor migration to Russia and Kazakhstan (Urinboyev 2017). It has been nearly 2 years since Shavkat Mirziyoyev took over the leadership of Uzbekistan. However, in contrast to early predictions, Mirziyoyev emerged as a reformoriented, ambitious, and pragmatic leader (Pannier 2017). Unlike the late president (Karimov) who did not allow any forms of critical 
views, President Mirziyoyev openly acknowledged the failure of public policies and showed his readiness to make changes (Buckley 2018). He is actively and publicly pursuing a number of simultaneous reforms to change the everyday life norm from "people should serve the government" to "the government should serve the people." What is especially relevant with regard to anticorruption is that he began his reforms by asking for input from citizens through online reception systems, commonly known among ordinary people as "portals" (e.g., https://my.gov.uz/oz). These provide information about the government and encourage citizens to report problems with service provision and corruption and give feedback on state policies. These online reception systems enable ordinary citizens, even those living in remote villages, to file complaints and request assistance on various issues.

However, it remains to be seen if the anticorruption initiatives of the new Uzbek leadership will produce any tangible results in the long run. In spite of the recent positive changes, deeper systemic and structural problems still remain unaddressed by the new Uzbek government. A recently published study indicates that online reception systems have had a very limited impact on the peripheries of Uzbekistan where there are no viable forms of accountability or incentive mechanisms that can make local government officials act in accordance with the centrally designed policies and laws (Urinboyev et al. 2018). It is highly likely that the Karimov-era type informal governance practices will persist unless measures adopted to promote good governance go beyond official proclamations and rhetoric. Accountability schemes need positive and negative incentives that are enforced from above in order to bring about real positive changes in everyday life. In the light of ongoing changes in Uzbekistan, there is a need for further research that investigates the state of corruption and the governance trajectories in the post-Karimov period.

\section{Concluding Remarks}

The chapter shows that the corruption in Uzbekistan is not only the outcome of kleptocratic practices and dysfunctional state institutions but is also a reflection of the general informalization of the state and society. Due to the inability of state to provide adequate social protection, the general population of Uzbekistan is compelled to turn to an informal coping mechanism to "get things done." Both people and public officials are increasingly reliant on the informal economic system. From this perspective, the apparent resilience of corruption in Uzbekistan, despite innumerable anticorruption and good governance projects of both Uzbek government and international actors, resides in its embeddedness in informal forms of coping strategies, and might be viewed as a result of the "absent state" that fails to meet the basic needs of its citizens. Any attempts at eliminating informal livelihood strategies, without creating alternatives, might destabilize and create social discontent in an already troubled and impoverished Uzbek society. Hence, anticorruption measures are not simply a matter of getting people to obey the law. It is more importantly about promoting socioeconomic change.

\section{Cross-References}

\author{
- Civil Service Development in Kazakhstan \\ - Governance in Tajikistan \\ - Local Government in Kazakhstan \\ - Local Government in Uzbekistan \\ - Public Administration in Kyrgyzstan \\ - Public Sector Reforms in Central Asia
}

\section{References}

Abramson DM (2000) Constructing Corruption: Foreign Aid, Bureaucratization, and Uzbek Social Networks. Unpublished paper presented at Harvard University. Retrieved from http://turkmeny.h1.ru/cas/abramson. html

Buckley N (2018, February) Once-repressive Uzbekistan begins a post-Karimov opening. Retrieved 19 May 2018, from https://www.ft.com/content/6c37419c0cbf-11e8-8eb7-42f857ea9f09

Collins K (2003) The political role of clans in Central Asia. Comp Polit 35(2):171-190

De Sardan J-PO (1999) A moral economy of corruption in Africa? J Mod Afr Stud 37(01):25-52 
Dillinger WR (2007) Poverty and regional development in Eastern Europe and Central Asia. World Bank Publications, Washington, DC

Ergashev B, Iusupov I, Pogrebniak A, Korenev I, Allaev B, Gaibullaev O, .., Saifulin R (2006) Public administration reform in Uzbekistan. Probl Econ Trans 48(12):32-82

Fane D (1996) Ethnicity and regionalism in Uzbekistan: maintaining stability through authoritarian control. In: Drobizheva L, Gottemoeller R, Kelleher CM, Walker L (eds) Ethnic conflict in the post-Soviet World: case studies and analysis. M. E. Sharpe, Armonk, pp 271-302

Fumagalli M (2007) Introduction: stability, sovereignty, and the resilience of politics under authoritarian rule. Centr Asian Surv 26(1):1-6

Gleason G (1995) Corruption, decolonization and development in Central Asia. Eur J Crim Policy Res 3(2):38-47

Habibov NN (2011) Public beliefs regarding the causes of poverty during transition: evidence from the Caucasus, Central Asia, Russia, and Ukraine. Int J Sociol Soc Policy 31(1/2):53-74

Heidenheimer AJ, Johnston M, Le Vine VT (1989) Political corruption: a handbook. Transaction Publishers, New Brunswick. Retrieved from http://www.mtas.ru/search/ search_results.php?publication_id $=2319$

Hohmann S, Mouradian C, Serrano S, Thorez J (2014) Development in Central Asia and the Caucasus: migration, democratisation and inequality in the post-Soviet Era. I.B. Tauris, London

Humphrey C (2002) The unmaking of Soviet life: everyday economies after socialism. Cornell University Press, Ithaca

Ilkhamov A (2004) The limits of centralization: regional challenges in Uzbekistan. In: The transformation of Central Asia. States and Societies from Soviet Rule to Independence. Cornell University Press, Ithaca, pp 159-181

Ilkhamov A (2007) Neopatrimonialism, interest groups and patronage networks: the impasses of the governance system in Uzbekistan. Centr Asian Surv 26(1):65-84

Ilkhamov A (2013) Labour migration and the ritual economy of the Uzbek extended family. Z Ethnol 138(2):259-284

Ilkhamov A (2017) Grand corruption in Uzbekistan's telecommunication sector: root causes and social costs. In: Laruelle M (ed) Constructing the Uzbek state: narratives of post-Soviet years. Lexington Books, Boulder, pp 45-68

IMF (2012) Republic of Uzbekistan and the IMF. International Monetary Fund. Retrieved from http:// www.imf.org/external/country/UZB/index.htm

Johnson E (2007) Post-Soviet welfare provision: state or society? In: Annual Meeting of the American Political Science Association. Chicago. Retrieved from http:// www.allacademic.com/meta/p211476_index.html
Kandiyoti D (2007) Post-Soviet institutional design and the paradoxes of the Uzbek path. Centr Asian Surv 26(1):31-48

Karimov I (1993) Building the future: Uzbekistan - its own model for transition to a market economy, Tashkent, Sharg

Karklins R (2002) Typology of post-communist corruption. Probl Post Commun 49(4):22-32

Knack S (2006) Measuring corruption in Eastern Europe and Central Asia: a critique of the cross-country indicators. World Bank Policy Research Working Paper, 3968. Retrieved from http://papers.ssrn.com/sol3/ papers.cfm?abstract id $=923275$

Kubicek P (1998) Authoritarianism in Central Asia: curse or cure? Third World Q 19(1):29-43

Ledeneva AV (2013) Can Russia modernise?: sistema, power networks and informal governance. Cambridge University Press, Cambridge

Lewis DG (2016) Tackling corruption in Uzbekistan: a white paper. Open Society Foundations, New York

Luong PJ (2004) The transformation of Central Asia. States and ocieties from Soviet Rule to Independence. Cornell University Press, Ithaca

Markowitz LP (2008) Local elites, prokurators and extraction in rural Uzbekistan. Centr Asian Surv 27(1):1-14

Megoran N (2017) Nationalism in Central Asia: a biography of the Uzbekistan-Kyrgyzstan Boundary. University of Pittsburgh Press, Pittsburgh

Pannier B (2017) Analysis: how high should hopes be for change in Uzbekistan? Retrieved 16 July 2018, from https://www.rferl.org/a/uzbekistan-mirziyoev-hopes-forchange-karimov-cotton-foreign-policy/28938193.html

Pashkun D (2003) Structure and Practice of the State Administration in Uzbekistan. Discussion Paper No. 27. Open Society Institute, Budapest

Perlman BJ, Gleason G (2007) Cultural determinism versus administrative logic: Asian values and administrative reform in Kazakhstan and Uzbekistan. Int J Public Adm 30(12-14):1327-1342

Polese A (2008) "If I receive it, it is a gift; if I demand it, then it is a bribe": on the local meaning of economic transactions in post-Soviet Ukraine. Anthropol Action 15(3):47-60. https://doi.org/10.3167/aia.2008.150305

Poliakov S (1992) Everyday Islam: religion and tradition in rural Central Asia. M.E. Sharpe, New York

Pomfret R (2000) The Uzbek Model of Economic Development, 1991-99. Econ Transit 8(3):733-748

Rasanayagam J (2011) Informal economy, informal state: the case of Uzbekistan. Int $\mathrm{J}$ Sociol Soc Policy 31(11/12):681-696

Rivkin-Fish M (2005) Bribes, gifts and unofficial payments: rethinking corruption in post-Soviet Russian health care. In: Haller D, Shore C (eds) Corruption: anthropological perspectives. Pluto Press, London/ Ann Arbor, pp 47-64. Retrieved from http://www. untag-smd.ac.id/files/Perpustakaan_Digital_1/CORR UPTION\%20Haller_Corruption-Anthropological\%20 Perspectives.pdf\#page $=51$ 
Ruziev K, Ghosh D, Dow SC (2007) The Uzbek puzzle revisited: an analysis of economic Performance in Uzbekistan since 1991. Centr Asian Surv 26(1):7-30

Sneath D (2002) Reciprocity and notions of corruption in contemporary Mongolia. Mongolian Stud 25:85-99

Spechler MC (2002) Free at last? Uzbekistan and Russia. Probl Post Commun 49(1):63-67

Spoor M (1995) Agrarian transition in former Soviet Central Asia: a comparative study of Uzbekistan and Kyrgyzstan. J Peasant Stud 23(1):46-63

Staples J (1993) Soviet use of corruption purges as a control mechanism: the Uzbekistan case. Past Imperfect 2:29-48

Sun Y (2004) Corruption and market in contemporary China. Cornell University Press, Ithaca/London

Taksanov A (2000) 'Tsentral'naya Aziya: Piramida Korruptsii Zdes' Prostoit Tysiacheletiya' (Central Asia: the pyramid of corruption will be standing there for ages). Internet-Gazeta Navig, July 14

TI (2016) Corruption Perceptions Index 2016, Transparency International. Retrieved 10 June 2017, from https://www.transparency.org/news/feature/corruption _perceptions_index_2016

Trevisani T (2007) After the Kolkhoz: rural elites in competition. Cent Asian Surv 26(1):85-104

Urinboyev R (2013) Living law and political stability in post-Soviet Central Asia. A case study of the Ferghana Valley in Uzbekistan. PhD Dissertation, Lund Studies in Sociology of Law, Lund University, Lund

Urinboyev R (2017) Establishing an "Uzbek Mahalla" via smartphones and social media: everyday transnational lives of Uzbek labor migrants in Russia. In: Laruelle M (ed) Constructing the Uzbek state: narratives of post-Soviet years. Lexington Books, Boulder, pp 119-148
Urinboyev R, Polese A, Svensson M, Adams LL, Kerikmäe T (2018) Political vs everyday forms of governance in Uzbekistan: the illegal, immoral and illegitimate politics and legitimacy in post- Soviet Eurasia. Stud Trans States and Soc 10(1):50-64

Urinboyev R, Svensson M (2013) Living law, legal pluralism, and corruption in post-Soviet Uzbekistan. J Leg Pluralism Unoff Law 45(3):372-390

Urinboyev R, Svensson M (2017) Corruption, social norms and everyday life in Uzbekistan. In: Kubbe I, Engelbert A (eds) Corruption and norms: why informal rules matter? Palgrave, Basingstoke, pp 187-210

Varese F (2001) The Russian mafia: private protection in a new market economy. Oxford University Press, Oxford

Wanner C (2005) Money, morality and new forms of exchange in postsocialist Ukraine. Ethnos 70(4): 515-537. https://doi.org/10.1080/00141840500419782

Warikoo K, Norbu D (1992) Ethnicity and politics in Central Asia. South Asian Publishers, New Delhi

Wegerich K (2006) “A little help from my friend?” Analysis of network links on the meso level in Uzbekistan. Cent Asian Surv 25(1-2):115-128

Werner CA (2000) Gifts, bribes, and development in postSoviet Kazakstan. Hum Organ 59(1):11-22

World Bank (1999) Uzbekistan: social and structural policy review. World Bank Report No 19626. Washington, DC

World Bank (2014) Worldwide Governance Indicators: Uzbekistan. Washington, DC. Retrieved from http:// databank.worldbank.org/data/views/variableselection/ selectvariables.aspx? source $=$ worldwide-governanceindicators\#c_u

Zettelmeyer J (1998) The Uzbek growth puzzle. Working Paper of the International Monetary Fund. International Monetary Fund, WP/98/133 